\title{
Working
}

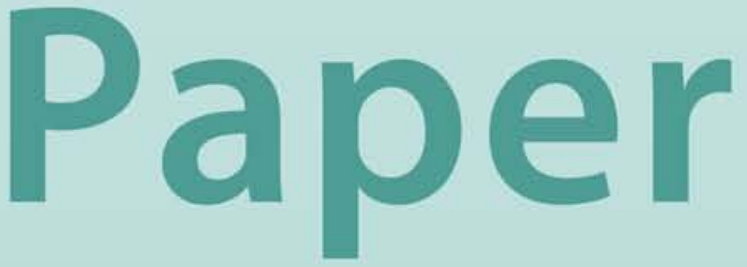


Emergency Liquidity Support Facilities

Dong He 


\title{
IMF Working Paper
}

Monetary and Exchange Affairs Department

\section{Emergency Liquidity Support Facilities}

\author{
Prepared by Dong $\mathrm{He}^{\mathrm{L}}$
}

Authorized for distribution by Charles Enoch

April 2000

\begin{abstract}
The views expressed in this Working Paper are those of the author(s) and do not necessarily represent those of the IMF or IMF policy. Working Papers describe research in progress by the author(s) and are published to elicit comments and to further debate.
\end{abstract}

This paper discusses operational aspects of official emergency liquidity support to individual institutions under stress. It argues that properly designed lending procedures, clearly laid-out authority and accountability, as well as disclosures rules, will promote financial stability, reduce moral hazard, and protect the lender of last resort from undue political pressure. Although there may well be good reasons to maintain ambiguity over the conditions for assistance, there are important advantages for developing, and for transition economies to follow a rule-based approach by setting out ex ante the necessary conditions for support, while maintaining that meeting such conditions is not sufficient for receiving support.

JEL Classification Numbers: E58, G21, G28

Keywords: Lender of Last Resort, Emergency Liquidity Support

Author's E-Mail Address: dhe@imf.org

\footnotetext{
${ }^{1}$ The author would like to thank the principal reviewers of the paper, Huw Evans and Haizhou Huang, for their detailed comments and suggestions. Comments from V. Sundararajan, Charles Enoch, Alain Ize, Barry Johnston, Marc Quintyn, Gillian Garcia, Claudia Dziobek, Barbara Baldwin, Greta Mitchell-Casselle, Peter Hayward, Luis Jacome Hidalgo, Matthew Jones, Arto Kovanen, and Jan Willem van der Vossen are also gratefully acknowledged.
} 


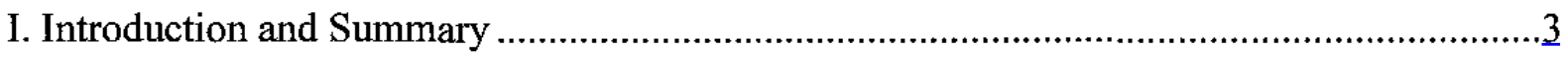

II. The Nature and Scope of Emergency Liquidity Support ..................................................... $\underline{6}$

A. Definition and Objectives of LOLR Support.......................................................... 6

B. The Meaning of "Last Resort" ............................................................................

C. The Resource Constraint On LOLR Operations ...................................................... 9

III. Transparency and Ambiguity in Emergency Liquidity Support....................................10

A. Constructive Ambiguity .............................................................................10

B. The Preconditions for LOLR Support .............................................................13

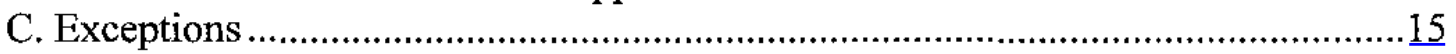

D. Ex Post Transparency in LOLR Support ............................................................17

IV. Modalities of Emergency Liquidity Support ………...................................................

A. The Instruments of Support.......................................................................18

B. The Collateral Requirement ........................................................................19

C. Interest Rates and Supervisory Sanctions ........................................................20

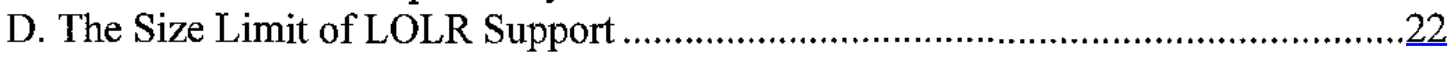

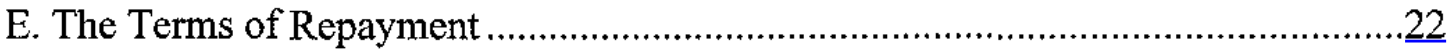

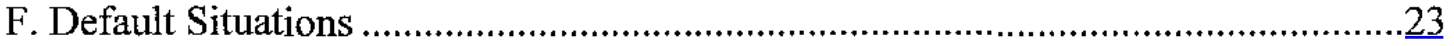

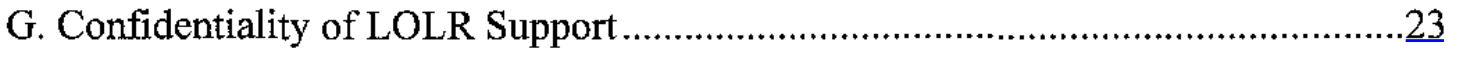

V. Emergency Liquidity Support in Times of Systemic Crises...............................................24

Boxes

1. Key Considerations of Emergency Lending in Normal Times........................................... 4

2. Key Considerations of Emergency Lending in Systemic Crises ....................................... $\frac{5}{6}$

3. United Kingdom: Memorandum of Understanding Between HM Treasury, ....................16

Appendix Tables

1. Provisions on Emergency Liquidity Support in Selected Central Bank Legislation...........27

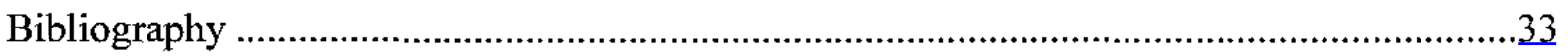




\section{INTRODUCTION AND SUMMARY}

This paper discusses the operational aspects of emergency liquidity support by central banks to individual institutions under stress. ${ }^{2}$ Recent financial crises around the world have prompted renewed interest in lender-of-last-resort (LOLR) support as a key component of the public financial safety nets. Although the basic principles of emergency lending, as developed by Thornton and Bagehot, have been known for more than a century, in practice its use has been subject to considerable difficulties. The exercise of the emergency lending function, as contrasted with lending as part of standard money market practice, generally occurs in circumstances where the solvency of the borrowing bank is subject to doubt. Typically, difficult decisions on whether to grant or deny credit to an institution seeking help have to be made rapidly and executed within a short period of time, and a delicate balance has to be struck between controlling moral hazard and avoiding systemic instability.

The study of emergency lending operations is hampered by a general lack of information on country practices in this area. There is a tradition among central banks of not saying much on the subject, both ex ante and ex post. Nevertheless, this paper attempts to distill some common lessons from a variety of approaches to emergency support operations in different countries, based on the limited information available. It will aim to shed light on the following operational questions: Should emergency liquidity support facilities exist? If such facilities exist, should their existence be known to the public? Should the operational rules of such facilities be specified ex ante? Should there be disclosure of emergency lending operations ex post? What roles should the central bank, the supervisory agency, and the ministry of finance play in conducting emergency liquidity support? How to ensure that monetary and exchange rate policy objectives are not vitiated by emergency liquidity support? What should be the terms and conditions for emergency liquidity support? What happens if preconditions of support are not met? What should be done in default situations? Should the modalities of emergency lending be different in times of systemic crisis from normal times?

The paper will argue that, although there may well be good reasons to maintain ambiguity over the conditions for LOLR support and to avoid ex ante specification of the rules to follow in such operations, it is increasingly more attractive to follow a rule-based approach by setting out the necessary conditions for support, while maintaining that meeting such conditions is not sufficient for receiving support. This is particularly true for developing and transitional economies, where central bank discretion itself is more likely to be subject to undue political pressure and regulatory forbearance, and lead to the abuse of LOLR support facilities. Whether there is ex ante specification or not, it is essential to have properly designed lending procedures, clearly laid out authority and accountability, as well as rules for

${ }^{2}$ This paper does not attempt to provide a comprehensive survey of the literature on the theoretical aspects of the subject. For such a survey, see, for example, Freixas et al (1999). 
ex post disclosure when such disclosure will not be disruptive to financial stability, in order to ensure accountability and to reduce the distortionary effect on incentives.

Another argument is that emergency liquidity support facilities are primarily for systemic purposes and should be used very infrequently. Decisions to lend to systemically important institutions at the risk of insolvency or without sufficient good quality collateral should be made jointly by the monetary, the supervisory, and the fiscal authorities. Lending to nonsystemically important institutions, if any, should be made only to those that are deemed to be solvent and have sufficient, acceptable collateral. When support has to be provided, it is essential that such support be made only on a short-term basis. Banks that receive such support should be subject to enhanced supervision and restrictions on activities, and a clear exit strategy should be designed so that the banks that prove to be unviable will be closed or resolved in an orderly fashion (see Box 1). In any case, it is the responsibility of the central bank to ensure that its monetary and exchange rate policy objectives are not vitiated by its emergency lending.

Box 1. Key Considerations of Emergency Lending in Normal Times

- Have in place clearly laid out lending procedures, authority, and accountability.

- Maintain close cooperation and exchange of information between the central bank, the supervisory authority (if it is separate from the central bank), the deposit insurance fund (if such a fund exists), and the ministry of finance.

- Decisions to lend to systemically important institutions at the risk of insolvency or without sufficient, acceptable collateral should be made jointly by the monetary, supervisory, and the fiscal authorities.

- Lending to nonsystemically important institutions, if any, should be only to those institutions that are deemed to be solvent and with sufficient acceptable collateral.

- Lend speedily.

- Lend in domestic currency.

- Lend at above average market rates.

- Maintain monetary control by engaging effective sterilization.

- Subject borrowing banks to enhanced supervisory surveillance and restrictions on activities.

- Lend only for the short term, preferably not exceeding three to six months.

- Have a clear exit strategy.

- Emergency support operations should be disclosed when such disclosure will not be disruptive to financial stability. 
In times of systemic crises, the modalities of LOLR support will need to be adapted from good practices in normal times. In a general environment of panic and instability, the existence and presence of an emergency lender should not be doubted by the market participants. The central bank should pronounce its willingness to lend and its support should be visible. Decisions to provide support should be part of a general crisis management strategy and should be made jointly by the monetary, the supervisory, and the fiscal authorities. The repayment terms may be relaxed to accommodate the implementation of the bank restructuring strategy. Emergency liquidity support in these circumstances should be explicitly guaranteed by the government and any loss thus incurred should be fully compensated by the budget (see Box 2).

The rest of the paper is organized as follows. Section II discusses the nature and scope of emergency support operations. Section III discusses the issues that relate to the transparency and ambiguity in LOLR support. Section IV discusses the modalities of emergency lending to specific banks in normal times, and Section V discusses emergency lending in times of systemic crises. The Appendix lists selected texts of central laws that deal with emergency liquidity support in twenty countries.

\section{Box 2. Key Considerations of Emergency Lending in Systemic Crises}

- Have in place clearly laid out lending procedures, authority, and accountability.

- Maintain close cooperation and exchange of information between the central bank, the supervisory authority (if it is separate from the central bank), the deposit insurance fund (if such a fund exists), and the ministry of finance.

- Make public announcement of willingness to lend.

- Decisions to provide support should be part of a general crisis management strategy and should be made jointly by the monetary, the supervisory, and the fiscal authorities.

- Lend speedily.

- Lend in domestic currency.

- Lend at above average market rates.

- Maintain monetary control by engaging effective sterilization.

- Subject borrowing banks to intensive supervisory surveillance and restrictions on activities.

- Repayment terms may be relaxed to accommodate the implementation of a systemic bank restructuring strategy.

- Emergency support operations should be disclosed when such disclosure will not be disruptive to financial stability. 


\section{The NATURe AND SCOPE OF EMERgenCy LIQUIDITY SUPPORT}

\section{A. Definition and Objectives of LOLR Support}

LOLR support can be defined as "the discretionary provision of liquidity to a financial institution (or the market as a whole) by the central bank in reaction to an adverse shock which causes an abnormal increase in demand for liquidity which cannot be met from an alternative source (Freixas et al, 1999)." ${ }^{3}$ The relative importance of lending through the discount window to target aid to specific banks and lending to the market through open market operations varies across countries and according to circumstances. There is a school of thought that advocates that the lender of last resort rely solely on open market operations rather than lending to specific institutions, in order to counter the moral hazard, which is often associated with discount window lending (Goodfriend and King, 1988). It is argued that liquidity assistance to banks through open market operations will filter through to the whole financial system through financial markets. However, such filtering may not occur in times of stress when confidence is low and the market becomes segmented. Indeed, Goodhart and Huang (1998) argue that adopting the view that the LOLR should lend only to the market is to reject the notion of the lender of last resort. In practice, many central banks combine use of the discount window with open market operations. This paper will focus on emergency support through discount window lending to specific banks. ${ }^{4}$

Discretionary emergency lending through the discount window typically has the following primary objectives: (1) to prevent illiquidity at an individual bank from unnecessarily leading to its insolvency; (2) to avoid runs that spill over from bank to bank. The first objective is related to the problem of fire-sale induced insolvency. A distinguishing feature of banks is that their assets are largely illiquid term loans while their liabilities comprise predominantly unsecured short-term deposits. Moreover, deposits are paid out in full on a first-come-first served basis. These features of banks' balance sheets make them susceptible to depositor runs. If a bank that experiences a significant deposit run cannot

\footnotetext{
${ }^{3}$ In this definition, LOLR support or emergency lending does not include standing facilities, which are standard monetary policy instruments. Accordingly, this paper does not consider the operations of standing facilities.

${ }^{4}$ LOLR support could also take the form of off-balance sheet guarantees. The central bank, as the crisis manager, could orchestrate a rescue operation by providing an indemnity to a third party (for example, the peer group of the bank seeking liquidity support) that is willing to take part in the operation, rather than providing funds itself on-balance sheet. This practice is not recommended as a good practice since it is often done in a nontransparent manner. However, if it is used, it is important for the central bank's contingent liabilities to be properly and transparently recognized and recorded.
} 
quickly attract sufficient replenishing funds to offset deposit loss, it may be required to sell at least some assets quickly at fire-sale prices. To avoid selling assets at fire-sale prices, troubled institutions require one or both of the following: a recycling of funds from deposit gaining institutions or access to credit from other parties. If other private banks do not provide such assistance, then the central bank may have to be approached for liquidity support as the LOLR.

The second objective is related to the problem of contagion. Contagion is a term used to describe the spillover of the effects of shocks from one or more banks to others. Bank contagion is of particular concern if adverse shocks, such as the failure or near-failure of one or more banks, are transmitted in domino fashion not only to other banks and the banking system as a whole, but beyond to the entire financial system and the macroeconomy. Banking is subject to contagion for the following reasons: first, banks typically lend heavily to each other; when a particular bank is subject to runs, it will have to recall its interbank loans to other banks immediately, which may cause the other banks to become illiquid; second, asymmetric information is typically a very serious problem with banking. Incomplete and costly information may make it difficult for depositors to distinguish sound from unsound banks.

Emergency support operations are risky business. In providing support, the central bank is taking credit risks that are unacceptable to all other lenders in the market. While such lending is meant to bridge a temporary period of illiquidity for institutions that prove to be viable after the event, the institutions that receive such loans could turn out to be nonviable and have to be closed eventually. In these cases, emergency lending could still serve a useful public purpose, in providing time for the authorities to arrange for the orderly closure and resolution of failing institutions.

However, there are important costs associated with prolonged lending to troubled institutions. Such lending, for example, can allow uninsured depositors and other general creditors to exit a failing bank before its closure. When fully collateralized central bank loans replace funds that are not insured, the deposit insurance fund may face higher resolution costs. In addition, a perception that LOLR assistance will be readily available to troubled institutions can weaken market discipline in the banking system, and remove some of the pressure on bank regulators and supervisors to close troubled institutions promptly.

To minimize such costs, it is essential any LOLR support must be primarily for systemic purposes. This means that in considering whether to provide LOLR support to an individual institution, the guiding principle must be whether the failure of that institution would, either by itself or through spreading contagion to other institutions, damage the stability of the financial system. Such a contagion effect could arise, for example, where other institutions are heavily exposed to the troubled institution or share similar characteristics, which could be interpreted as the origin of its problems. The vulnerability of other institutions to the contagion effect will also depend on the general tone of sentiment at the time, e.g., whether there is heightened nervousness about the stability of the banking or the monetary systems (Yam, 1999). If LOLR support is considered in any nonsystemic cases, 
it should be confined to institutions that are deemed to be solvent and normally with acceptable collateral.

\section{B. The Meaning of "Last Resort"}

In considering the use of emergency lending facilities, central banks typically require the borrower to demonstrate that the LOLR support is genuinely being sought as a last resort, and it has made all reasonable efforts to raise the necessary liquidity. There are two approaches to ensuring that LOLR support will be sought only as a means of last resort. Firstly, the support is to be provided at a penal interest rate. The difficulty with this approach is that it is often not easy to determine what is the right level of penalty and what interest rate should be charged, particularly when there is market segmentation or breakdown. In addition, adverse selection may imply that problem banks are not necessarily deterred by penalty interest rates (see further discussion in Section IV). The second approach is to impose harsh conditionality on the borrowing bank as an implicit price. This has been the typical approach of the Federal Reserve in the United States. Many central banks typically have resorted to both approaches to ensure that the assistance was sought genuinely as a last resort.

Regulation A of the Federal Reserve Board in the United States stipulates that banks must first exhaust market sources of funds before turning to the discount window. To ensure that this principle is met in practice, reserve banks regularly monitor the sources and uses of funds for institutions while they are borrowing (Clouse, 1994). In Hong Kong, as a precondition for support, HKMA requires that "the institution has sought other reasonably available sources of funding before seeking LOLR assistance," and "the shareholder controllers of the institution have made all reasonable efforts to provide liquidity and/or capital support as a demonstration of their own commitment (Yam, 1999)."

The Bank of England (BOE) was traditionally as much a crisis manager as a crisis lender in dealing with banking problems, by playing a managerial, facilitating, or coordinating role. Governor Eddie George (George, 1993) pointed out that, as one of the operational principles, the BOE would explore every option for a commercial solution before committing the BOE's funds. Initially, the BOE would always look to major shareholders to provide support. Short of that, the BOE would encourage the troubled bank to try to find a buyer, for some or all of itself, even at reduced prices. Or a bank's major creditors may decide to provide support to protect their own positions. Or there may be a coherent group of other banks with a common interest in an orderly resolution. It is only when these options have been exhausted that the BOE will consider providing support itself-and even then the BOE may decide against it, as it did in the case of British and Commonwealth Merchant Bank in 1990. Exploring these options does not necessarily imply it will take longer to make decisions whether to grant support or not. Speed is of the essence in handling liquidity problems. Many of these options were tried over the weekend by the BOE in handling the failure of Barings in early 1995. 


\section{The Resource Constraint On LOLR Operations}

Central banks are often thought of as having unlimited access to resources, since they can print money, but this is clearly simplistic (Giannini, 1999). Lending freely in a crisis may prove incompatible with the prevailing monetary regime. This is most clearly demonstrated by the constraints that a fixed exchange rate system places on the capacity for domestic money creation. Moreover, large loans to institutions at the risk of insolvency pose substantial credit risks to the central bank, which could complicate monetary management and contribute to inflation since central banks typically have minimal capital and a small revenue base, and tend to monetize their losses. Thus, when the scale of support is large, there is the need for the fiscal authorities to underwrite the credit risks taken on by the central bank. The ministry of finance will have to be involved in making decisions to lend to systemically important institutions at the risk of insolvency. As Goodhart and Schoenmaker (1993) point out, "he who pays the piper calls the tune."

Sterilization of the liquidity support provided through emergency lending facilities would enable central banks to recycle liquidity in the banking system, and facilitate monetary control and exchange market stability. However, the extent of successful sterilization depends on the availability of necessary instruments and overall monetary and macroeconomic conditions. In the recent Asian crises, large amounts of liquidity support to problem financial institutions had to be sterilized; this was, to a large extent, accomplished in Korea and Thailand but not in Indonesia, leading to a loss of monetary control in that country. In Indonesia, the consequent inflation and exchange rate depreciation led to more loss of confidence in the banks, making further liquidity support necessary. Until this vicious cycle was broken, the highly expansionary monetary policy resulted in high inflation, capital outflows, and a collapse of the rupiah.

Central banks need to have the necessary instruments to sterilize the additional liquidity. These include discretionary market-based instruments (such as reverse repos and foreign exchange swaps), standing facilities (such as a deposit facility), and higher reserve requirements. Given the difficulties in using higher reserve requirements in a time of banking crisis or distress, market-based instruments are preferable. This argues for developing deep and liquid money and securities markets as part of a sound banking system. Even with such markets, the inevitable market segmentation that emerges during a banking crisis will make volatility of interest rates unavoidable while sterilizing emergency liquidity support.

The resource constraint on the scope of emergency liquidity support is most apparent under a Currency Board Arrangement (CBA). Under the CBA, the central bank can provide LOLR support provided that they have sufficient excess coverage of foreign reserves or support from a common pool of bank resources, for example, interbank borrowing by the central bank. One solution, adopted in Bulgaria, is to set up a separate department (the banking department) within the central bank that is endowed with sufficient resources to lend 
in the event of a panic or banking sector problems. Should the CBA permit, ${ }^{5}$ the central bank may obtain automatic support from other central banks, as in Hong Kong, where a protocol of this kind was established with other Asian central banks in the wake of the Mexican crisis, or it may guarantee lines of credit with foreign banks on behalf of local commercial banks, as implemented by Argentina. ${ }^{6}$

A crucial consideration is the resources available to the central bank, and the legal and other limitations placed on the central bank in the exercise of its role as the LOLR. In order not to undermine the CBA, the central bank must be prudent in the use of the excess coverage. ${ }^{7}$ The authority and conditions for accessing different sources of funds should be clearly laid out in the legislation or regulation governing emergency support operations.

More generally, it is recognized that, while historically the central bank has usually been the lender of last resort, this role does not have to fall exclusively within the responsibility of the central bank. If a certain authority and access to resources are necessary for taking the leading role in managing a liquidity crisis, then a ministry of finance may be able to do it as well as a central bank (Fischer, 1999). If the central bank is not in a position to play the role of the lender of last resort, a special fund for emergency lending purposes may be set up by the ministry of finance. In such cases, it would be essential to establish full transparency with regard to the operation of the fund, and to seek the cooperation of the central bank and the supervisory authority in making decisions when the fund is to be drawn upon for emergency liquidity support.

\section{TRANSPARENCY AND AMBIgUITY IN EMERgenCY LIQUIDITY SUPPORT}

\section{A. Constructive Ambiguity}

One possible way to avoid moral hazard in performing the function of emergency liquidity support is to make access to such facilities uncertain, something to be determined ad hoc in each situation. "A lender of last resort should exist, but his presence should be doubted" (Kindleberger, 1978). A tradition of constructive ambiguity has been practiced by

\footnotetext{
${ }^{5}$ International reserves required for backing in Argentina, Bulgaria, and Lithuania are calculated using the concept that it does not take into account the central bank's long-term external obligations (for example, to the IMF or the World Bank).

${ }^{6}$ Under this agreement, participating banks pay a premium to the central bank, which, in turn, pays a commission to the international banks to secure access to the funds. Local banks in need of funds will have to place certain securities with the central bank, which will enter into repurchase agreements with participating international banks.

${ }^{7}$ When the excess coverage becomes small, the CBA's credibility will come under serious scrutiny. Thus, if the excess coverage is limited, the case for not assuming the role of LOLR by the central bank under a CBA becomes strong.
} 
some central banks. This is clearly illustrated by the following statement by Gerald Corrigan, President of the Federal Reserve Bank of New York, before the United States Senate Committee on Banking, Housing, and Urban Affairs in May 1990:

"I believe that the workings of both the safety net and market discipline will be better served in a context in which the authorities maintain a policy of what I like to call 'constructive ambiguity' as to what they will do, how they will do it, and when they will do it. ...The circumstances associated with a particular case, the setting in which it occurs, and the assessment of the relative costs and benefits of alternative courses of action will always have to be looked at case by case. But in no case should it be prudent for market participants to take for granted what actions the authorities will take and certainly in no case should owners and managers of troubled institutions-large or small--conclude that they will be protected from loss or failure (Corrigan, 1990)."

In a similar vein, the Governor of the Bank of England, Eddie George, stated that

"In reaching a decision on support, we take care not to be predictable. Central bankers have raised unpredictability to an art form, so that the phrase 'constructive ambiguity' has become rather popular in our circles. But it is essential that no one-no one--should expect support as a matter of course. I often hear it said that some banks are 'too big to fail,' that some occupy such key positions that their failure is almost unthinkable. It is, indeed, true that size is an important factor in considering systemic effects. Even so, I have to say that there is nothing automatic about our acting as lender of last resort, and even if we did decide on support, no bank should assume that it would be immune from penalty (George, 1993)."

There are, however, increasing moves toward transparency in the authorities' policy for handling problem banks, particularly in setting out the necessary conditions for support, while maintaining that meeting such conditions is not sufficient for receiving support. From the rational expectations perspective, economic agents will have some view of the likely extent of a financial safety net, so the possible existence of the safety net will have effects (both positive and negative) even if the central bank is not transparent in its intentions. Since managers, owners, creditors, and depositors must form some view as to the likelihood of the provision of a safety net, it is not obvious that ambiguity leads economic agents to believe the safety net will be less generous than what the central bank intends to provide (Enoch et al, 1997).

There are three reasons for an LOLR to spell out its rules to the extent possible (Fischer, 1999). First, by specifying a good set of rules, the central bank reduces the likelihood of unnecessary self-justifying crises. Second, by announcing and implementing a particular set of rules, the LOLR provides incentives for other stabilizing private sector 
behavior; for instance, in the holding of assets acceptable as collateral. Third, spelling out the rules in advance ties the hands of policymakers, reduces risks of politically motivated or spur-of-the-moment actions, and prevents any bias toward forbearance. The rules could be broken in extremis, but they still serve a useful purpose, since the LOLR would hesitate before incurring the cost of breaking them.

On the other hand, it is argued that a cookbook approach to problems in financial markets is likely to be inefficient (Quinn, 1996). It is impossible to determine in advance exactly in what form banking problems may emerge, and so it may not be possible to design effective operational rules to determine how the problems will be handled. Central banks will be reluctant to set out clear rules that they believe they may need to violate, in order not to jeopardize their own credibility. Accordingly, ambiguous but credible rules are viewed to be superior to transparent rules that lack credibility (Enoch et al, 1997).

In practice, there are a number of approaches to ex ante specification of the operational rules of LOLR operations. ${ }^{8}$ At one end of the spectrum, there is no reference to emergency support functions in the treaties establishing the European Monetary Union or the Statute of the European Central Bank (ECB). There is, thus, a great deal of uncertainty with regard to the ECB's role in maintaining financial stability. ${ }^{9}$ In the middle of the spectrum, many central bank laws or banking laws have a fairly general stipulation that the central bank may perform the emergency support function when necessary, without specifying how such a function should be performed. For example, Article 31 of the Reserve Bank of New Zealand Act stipulates that "the Bank shall, if the Bank considers it necessary for the purpose of maintaining the soundness of the financial system, act as lender of last resort for the financial system." Similarly, in Norway, Section 19 of the Norges Bank Act states "when warranted by special circumstances, the Bank may grant credit on special terms." In addition to the general stipulation in central bank laws that the central bank has the power to make emergency loans, some central banks have detailed internal regulations governing the principles and procedures of emergency lending, but such regulations are not made public, which is the case in Japan.

At the other end of the spectrum, central bank laws or regulations specify in detail a rule-based approach to emergency support operations. Examples include the United States, Hong Kong, and Bulgaria. In the United States, under the "Prompt Corrective Action" framework, the Federal Reserve Act and Regulation A on "Extension of Credit by Federal Reserve Banks" specify in detail the solvency and collateral requirements, repayment terms, and interest rates to be charged on emergency loans by the Federal Reserve. In Hong Kong, the HKMA has a policy statement on LOLR support specifying in detail the preconditions of support, the instruments for support as well as specifications of procedures to deal with cases

${ }^{8}$ The Appendix lists selected text of provisions on emergency liquidity support from central bank laws in twenty countries.

${ }^{9}$ See also Padoa-Schioppa (1999), and Prati and Schinasi (1998). 
that should be treated as exceptions to the rules. The National Bank of Bulgaria has a regulation with similar content.

Both theoretical arguments and country experiences lead to the conclusion that there is probably no single optimal approach to the question whether there should be ex ante specification of the operational rules of LOLR support. However, for developing and transition economies, there is a good argument that a rule-based approach looks more attractive than total discretion. These economies typically do not yet have a mature governance structure with checks and balances well established in the political system, and central banks are often under political pressure toward regulatory forbearance. A rule-based approach makes it easier to judge the appropriateness of the authorities' actions. In addition, in these economies, central banks as well as market participants have less experience in handling banking problems, and a rule-based approach is technically less challenging to implement.

\section{B. The Preconditions for LOLR Support}

A rule-based approach would make clear to market participants through legislation or supporting regulations, circulars, or policy statements the requirements and parameters in setting out the mechanics for LOLR support. The specification typically lays out the preconditions for support, the right to refuse to lend on the part of the central bank, and the decision process to deal with situations that need to be treated as exceptions to the rules.

As already discussed, the basic precondition for LOLR support is the judgment of the central bank, the supervisory authority, and the ministry of finance, that the failure of a troubled institution, if it is deprived of liquidity assistance, would damage the stability of the financial and monetary system. In addition, the following preconditions would typically apply:

(a) the institution is deemed to be solvent;

(b) the institution has sufficient collateral of acceptable quality; and

(c) the institution must be prepared to take appropriate remedial action to deal with its liquidity problems.

As a measure of whether an institution has a sufficient margin of solvency, the HKMA generally requires the institution to demonstrate that it maintains a capital adequacy ratio of at least 6 percent after making adjustments for any additional provisions that might be necessary. In Bulgaria, upon receipt of the application for an emergency support loan, the Banking Supervision Department of the BNB is required to present a written statement of opinion on the current solvency of the bank within 24 hours. In the United States, Regulation A of the Federal Reserve Board stipulates that before extending credit, a federal 
reserve bank should ascertain if an institution is undercapitalized or critically undercapitalized. ${ }^{10}$ A federal reserve bank may make or have outstanding advances to, or discounts for, a depository institution that it knows to be an undercapitalized institution, ${ }^{11}$ only:

(1) if, in any 120-day period, advances or discounts from any federal reserve bank to that institution are not outstanding for more than 60 days during which the institution is an undercapitalized institution; or

(2) during the 60 calendar days after the receipt of a written certification from the chairman of the board of governors or the head of the appropriate federal banking agency that the borrowing institution is viable; ${ }^{12}$ or

(3) after consultation with the board of governors.

A federal reserve bank may make or have outstanding advances to or discounts for a depository institution that it knows to be a critically undercapitalized depository institution only: ${ }^{13}$

(1) during the 5-day period beginning on the date the institution became critically undercapitalized; or

(2) after consultation with the board of governors.

${ }^{10}$ Changes in capital categories for depository institutions are tied to dates associated with official actions such as the required filing date for a Report of Condition and Income ("call report"), receipt of written notice from a primary regulator, or the delivery of a final report of examination.

${ }^{11}$ A bank is "undercapitalized" if the bank has (1) a total risk-based capital ratio that is less than 8 percent; or (2) a Tier 1 risk-based capital ratio that is less than 4 percent; or (3) has a leverage ratio that is less than 4 percent but not deemed as "adequately capitalized," or a leverage ratio that is less than 3 percent, if the bank is rated Composite 1 under the CAMELS rating system in the most recent examination of the bank and is not experiencing or anticipating significant growth

${ }^{12}$ A depository institution is deemed viable when the board of governors or the appropriate federal banking agency has determined, giving due regard to the economic conditions and circumstances in the market in which the institution operates, that the institution is not critically undercapitalized, is not expected to become critically undercapitalized, and is not expected to be placed in conservatorship or receivership. The board of governors believes that ordinarily an undercapitalized institution is viable if the appropriate federal banking agency has accepted a capital restoration plan for the institution, and the institution is complying with that plan.

${ }^{13}$ A bank is "critically undercapitalized" if the bank has a ratio of tangible equity to total assets that is equal to or less than 2 percent. 
If lending by the federal reserve exceeds these limits, and such lending causes losses to the FDIC, the federal reserve must reimburse the FDIC.

The determination of solvency of the potential borrower would entail the central bank having access to relevant supervisory information, which would necessitate close and continuous contacts with the supervisory authority, if the central bank itself is not the supervisory authority. In the United Kingdom, when the supervision function was being transferred from the Bank of England to the newly established Financial Services Authority, the two agencies, together with the Treasury, signed a Memorandum of Understanding in October 1997 that set out the role of each institution, and explained how they would work together toward the common objective of financial stability, including the gathering and sharing of information in the context of providing emergency support to financial institutions (see Box 3). The Reserve Bank of Australia and the Australian Prudential Regulation Authority have a similar memorandum in place. In Canada, the Financial Institutions Steering Committee (FISC), which is chaired by the Superintendent of the Office of the Superintendent of Financial Institutions (OSFI) and includes the Governor of the Bank of Canada, the Deputy Minister of Finance, and the Chairman of Canada Deposit Insurance Corporation (CDIC), serves as an important channel of communication and sharing of information in relation to crisis management.

\section{Exceptions}

When the preconditions on which central banks will normally be prepared to provide LOLR support are met, any such support would be provided at the discretion of the central bank or the monetary authority. Where the criteria are not met, decisions to grant or deny support will have to be made at certain prespecified levels of authority to ensure a clear demarcation of responsibility and accountability, and to ensure that any discretion and flexibility are matched by adequate checks and balances. Thus, if the institution is judged to be at the risk of insolvency, or it does not have in its possession sufficient good quality collateral, but it is still deemed necessary to provide support to the institution, then the fiscal authority should be consulted and the decision to lend should be made jointly by the central bank, the supervisory agency (if it is separate from the central bank), the deposit insurance fund (if such a fund exists), and the ministry of finance.

In the United States, before the FDIC can provide open bank assistance, ${ }^{14}$ it must establish that the assistance is the least costly to the insurance fund of all possible methods for resolving the institution. The FDIC may deviate from the least cost requirement only to avoid "serious adverse effects on economic conditions or financial stability" or "systemic risk" to the banking system. Only the Secretary of the Treasury has the power to grant this exception, after consulting with the President of the United States and with the

14 The term "open bank assistance" refers specifically to a resolution method where financial assistance is given to a troubled bank or thrift to prevent its failure. 
recommendation by two-thirds of the boards of directors of the FDIC and the Federal Reserve.

\author{
Box 3. United Kingdom: Memorandum of Understanding Between HM Treasury, \\ the Bank of England, and the Financial Services Authority
}

In the United Kingdom, since the task of banking supervision has been transferred from the Bank of England (BOE or the Bank) to the Financial Services Authority (FSA), the BOE and the FSA have joint responsibility for organizing banking rescues.

The Memorandum of Understanding establishes a framework for cooperation between HM Treasury, the BOE, and the FSA in the field of financial stability.

On emergency financial support, the memorandum states that:

"In exceptional circumstances, there may be a need for an operation which goes beyond the Bank's routine activity in the money market to implement its interest rate objectives. Such a support operation is expected to happen very rarely and would normally only be undertaken in the case of a genuine threat to the stability of the financial system to avoid a serious disturbance in the UK economy. If the Bank or the Financial Services Authority identifies a problem where such a support operation might be necessary, they would immediately inform and consult with each other.

Each institution would take the lead on all problems arising in its area of responsibility. The lead institution would manage the situation and coordinate the authorities' response (including support operations). The form of the response would depend on the nature of the event and would be determined at the time.

In all cases, the Bank and the Financial Services Authority would need to work together very closely and they would immediately inform the Treasury, in order to give the Chancellor of the Exchequer the option of refusing support action. Thereafter, they would keep it informed about the developing situation, as far as circumstances allowed."

On information exchange, the memorandum states that:

"The Financial Services Authority and the Bank will establish information sharing arrangements, to ensure that all information which is or may be relevant to the discharge of their respective responsibilities will be shared fully and freely. Each will seek to provide the other with relevant information as requested. The institution receiving this information will ensure that it is used only for discharging its responsibilities, and that it is not transmitted to third parties except where permitted by law."

In Argentina, the central bank law stipulates that "only when...ordinary or extraordinary circumstances so warrant in the judgment of an absolute majority of the board of directors, shall it be possible to exceed the allotments of time or to maximum amounts per institution." In Hong Kong, if the potential borrower is unable to comply with the preconditions for LOLR support, then funding support would only be provided with the specific prior approval of the Financial Secretary on its merits in light of the implications for systemic stability. In addition, the HKMA would consider whether to appoint a manager to safeguard the assets of the institution and to protect the interests of depositors and other creditors. 


\section{Ex Post Transparency in LOLR Support ${ }^{15}$}

In any decision as to whether to grant emergency lending facilities to a bank, there is always a risk that a bank that should be supported is not supported, and that one that should not be supported is. One clearly would wish for a system that would minimize the risk of such mistakes. A transparent rule-based system would seek to achieve that objective. However, mere specification of rules is not likely to give an unequivocal guide to actual policy in any individual case of a banking problem. For instance, in assessing whether a particular troubled bank should be supported, there may be questions as to whether the bank is insolvent or merely illiquid; ${ }^{16}$ there may be issues as to whether the bank is systemically important; and perhaps whether the bank has operated badly or was driven by factors beyond its control. Hence, even the prespecification of rules - i.e., ex ante transparency - will not necessarily be inconsistent with substantial operational discretion.

If the authorities are left with such discretion, it will be important to balance this discretion with "ex post" transparency, i.e., firm rules for disclosure after the event, and specified standards of accounting and auditing so that disclosure will be substantive and meaningful. ${ }^{17}$ Thus, the central bank should reveal-perhaps in a subsequent Annual Report-how much public funds were provided to problem banks, and what were the results. As on monetary issues, central bank (or supervisory agency) operational autonomy must be matched by accountability, i.e., the provision of detailed information after the event and the requirement to explain what has been done and to take responsibility for it. This is important not only to reassure the public that the authorities are operating competently and within the rules, but also to reassure the rest of the banking community, so that they can see what are the "rules of the game."

If a tradition of ex-post public disclosure exists, it may isolate the central bank from undue political pressures, since the knowledge that LOLR activities will eventually be disclosed may act as a restraint on improper use of the facility. Thus, it can act as a political shield for the central bank. It also raises the cost of using emergency support facilities for banks, since public revelation of their need for assistance is likely to impose a cost in terms of market discipline and, hence, reduce the moral hazard.

While there may well be reasons for not explaining immediately the full extent of financial support for a troubled bank, there must be an expectation that there will be full disclosure as soon as this is feasible without causing additional problems for the banking

\footnotetext{
15 This section draws heavily on Enoch et al (1997).

${ }^{16}$ Goodhart (1999) argues that it is generally not possible to distinguish between illiquidity and insolvency, particularly in times of crisis.
}

${ }^{17}$ This is consistent with the requirement of the IMF Code of Good Practices on Transparency in Monetary and Financial Policies. 
system. If this qualification implies that a very long delay in public disclosure would be required, there may be a strong argument that the support was inappropriate in the first place. It is very unlikely that financial support to a bank can be justified if the existence of that support has to be kept secret for a long time.

There are increasing moves to disclose emergency support operations by central banks. The Bank of Japan discloses regularly in its Annual Report details of emergency support, including the amount, maturity, collateral, and interest rate. The Bank of England discloses its financial support operations in footnotes to its financial accounts. ${ }^{18}$ In the "subsidiaries in liquidation" section, the Bank discloses the conditions of banks in financial difficulties that it has acquired. It discloses the name of the companies and total investments in them. The Bank also discloses its total provisions for bad loans to banks, which, in effect, provide an initial and partial public acknowledgement of the Bank's financial support operations. In Finland, the Bank of Finland (BOF) granted FM 1.9 billion to Skopbank in 1991 and FM 9.5 billion in 1992. Details of these loans were published in the BOF Bulletin (November 1992 and April 1993). Other financial agencies have also provided support to this bank. The nature and scope of this support was disclosed in the same editions of the BOF Bulletin.

\section{MODALITIES OF EMERGENCY LIQUIDITY SUPPORT}

\section{A. The Instruments of Support}

There are three basic instruments which are typically used by central banks to provide LOLR support to a troubled institution:

(1) discount of eligible paper (government securities, notes, drafts, and bills of exchange, etc.);

(2) advance with or without collateral; and

(3) repos of the institution's assets which are acceptable to the central bank (securities and possibly other assets, for example, placements with other banks).

For the consideration that commercial banks should be responsible for foreign exchange risk management themselves, LOLR support should be extended in domestic currency rather than in foreign exchange. This is consistent with the best practice in deposit insurance schemes that payments by the Deposit Insurance Fund should be made in domestic currency, for deposits denominated in both domestic currency and foreign currency. In the latter case, the conversion should be made at the exchange rate prevailing on the day the payment is made.

${ }^{18}$ The Bank of England reserves the right not to disclose its emergency lending to commercial banks, at least initially. 
In the United States, when obtaining credit in the form of a discount, the borrowing institution transfers eligible paper carrying its legal endorsement to the Federal Reserve Bank. In return, the borrower is credited in an amount equal to the discounted value of the eligible paper at the current discount rate. When the discount paper matures, it is returned to the borrower, and the borrower's reserve account is debited by the full amount of the paper. An advance is simply a loan by a federal reserve bank to the borrowing institution on its note secured by adequate collateral. At one time, discounts were the predominant form of discount window credit. From an operational perspective, however, advances are more convenient, and thus for many years all discount window credit has been in the form of advances. All discount window advances are demand loans and, hence, have no real maturity - they may be called at the discretion of the Reserve Bank. As a matter of convenience, discount officers may arrange to extend credit for a period of time without requiring the borrowing institution to make a formal request to renew the loan each day.

In order to mitigate the risk involved, central banks typically require that the value of the collateral used to secure LOLR funding in the form of advances or repos would exceed the principal amount of the funding according to the haircuts and loan to valuation ratios. In Hong Kong, for example, the HKMA would apply a 5 percent haircut to Exchange Fund Bills and Notes for repos, and loan to value ratio is 80 percent for credit facility secured by residential mortgages.

\section{B. The Collateral Requirement}

Central banks traditionally protect themselves by demanding collateral when making last-resort funding assistance to banks. By doing this, the LOLR avoids the need to form a judgment on the solvency of the institution applying for liquidity, while retaining the capacity to operate at the speed necessary to stay a run. At the same time, by basing the decision to lend on the availability of acceptable collateral, the LOLR reduces the moral hazard that the potential borrower would take excessive risks in its portfolio by holding assets that would not be accepted as collateral (Fischer, 1999).

However, an insolvent bank with some acceptable collateral that obtains an emergency loan can still adopt a go-for-broke strategy. While the LOLR may be protected, the Deposit Insurance Fund and the bank's other creditors (and society) are not. Conversely, a solvent bank with very large, immediate needs might have trouble providing enough collateral that is acceptable to the LOLR and might fail unnecessarily (Guttentag and Herring, 1983). Bagehot in fact recommended that the quality standards on collateral taken by the Bank of England during a crisis should be relaxed (Bagehot, 1873). If the LOLR, through its supervisory powers or those of another trusted agency, is reasonably assured of the solvency of the bank, it has little need for collateral.

In practice, country experiences vary greatly in terms of collateral requirement. The HKMA's policy is to accept only high quality paper (investment grade securities) and high quality residential mortgages as collateral. In the United States, although collateral is required for extended facilities under the discount window, a wide range of financial 
instruments is accepted, including government securities, corporate bonds and money market instruments, collateralized mortgage obligations, residential mortgage notes, commercial, industrial, and agricultural notes.

In Korea, the Bank of Korea may provide emergency liquidity support "against the collateral of any assets which are defined temporarily (italics added) as acceptable security" with the agreement of at least four members of the Monetary Policy Committee. In Japan, the Bank of Japan Law stipulates that the Bank of Japan "may provide uncollateralized loans (italics added) to financial institutions... and other financial business entities prescribed by a Cabinet Order...for a period within that prescribed by a Cabinet Order when they unexpectedly experience a temporary shortage of funds for payment due to accidental causes, including computer system problems, whereby the business operations of the financial institutions may be seriously hampered if the shortage is not recovered swiftly, provided that the advance is necessary to secure the smooth settlement of funds among financial institutions."

A good practice is for the central bank to announce ex ante that it will provide LOLR support normally only with collateral and specify what assets are considered as acceptable for such purposes, but also make it clear that it may be willing to relax the requirements under exceptional circumstances. In the situation where a decision is made to provide support to a systemically important bank which does not have sufficient collateral of acceptable quality, there are two approaches to take. One is to take every asset on the balance sheet of the borrowing bank (for example, loans and fixed assets) as collateral. One potential problem with this approach is that the central bank is not usually in a position to judge within a short period of time whether the borrowing bank has a clean title on the asset or whether the asset has already been pledged. The central bank's claim will be subject to legal challenges if the assets are already pledged. A second approach is to request the government to provide a guarantee for the central bank. The rationale for requesting such a guarantee is particularly strong if the central bank has serious doubts about the solvency of the bank.

\section{Interest Rates and Supervisory Sanctions}

It has been argued that a key element of the Bagehot rule of emergency lending is the prescription that the lender of last resort lend at "penalty" rates. ${ }^{19}$ However, a careful reading of Bagehot (1873) would attribute Bagehot's advocacy of a high lending rate to his view that internal and external drains typically accompany each other; the high rate was designed to stop the external drain (currency crisis), and lending freely would stop the internal drain

${ }^{19}$ Goodhart (1999) argues that it is not accurate to interpret Bagehot's rule of lending at "high" rate as lending at "penalty" rate, i.e., at a rate higher than that available in the market place. Fischer (1999) argues that the penalty rate need not be defined relative to the rate at which institutions would lend to each other in the market during a crisis. Instead, the penalty should be relative to the interest rate during normal times. 
(domestic bank runs) (Fischer, 1999). In an isolated case of funding difficulties in domestic currency, the effectiveness of charging penalty interest rate.would depend on the interest rate elasticity of demand for liquidity support. It can be argued that when a bank cannot borrow from the interbank market and is in urgent need of short-term liquidity, its demand for LOLR liquidity support would not be very elastic - thus, charging a penalty rate would not necessarily discourage the bank to approach the central bank for support. In addition, if the bank is fundamentally insolvent, then its demand for LOLR support would be inelastic and, in such cases, charging a penalty rate would not be effective. In other words, price signals would fail to act as a rationing device in the face of adverse selection.

On the other hand, if restrictive limits on the quantities a bank may borrow exist, they may be interpreted as implicit prices (Benston et al, 1986). The larger the role of quantitative rationing and implicit prices, the less important the explicit pricing of the restricted lending becomes. In practice, this often means that banks which receive nonpenalty rate funding assistance from the central bank are subject to more intensive supervisory surveillance and are prohibited from engaging in certain activities such as making new loans and paying out dividends.

In practice, interest rates policy on emergency liquidity support differs from country to country. In Japan, central bank loans to problem banks were often charged the official discount rate. In Hong Kong, the HKMA's policy is to charge its LOLR facilities "at the prevailing base rate plus a margin to be determined taking into account current market conditions." In Canada, the interest rate Bank of Canada charges on its emergency support loans is at least equal to the bank rate, which is typically 25 basis points above the average cost of overnight funds in the market. In the United States, the Federal Reserve policy is to charge the basic discount rate for the first thirty days of borrowing, and a flexible rate that takes into account rates on market sources of funds, but in no case will the rate charged be less than the basic discount rate plus one-half percentage point. The flexible rate also could be applied sooner than thirty days at the discretion of the lending federal reserve bank. The policy of charging the basic discount rate has, in the past, meant subsidies to the borrower since the basic discount rate was below the average interbank market rate.

Given that the underlying solvency position of the borrowing bank is not always obvious when LOLR support is sought, a good practice is to have a combination of both explicit and implicit prices. The explicit price should be marginally above the average market interest rate, with perhaps higher penalty attached to longer term borrowing. An excessively high penalty could make matters worse, not better, for the borrowing institution, which is typically in a fragile condition. As an implicit price, the borrowing bank would have to implement a liquidity restoration plan that is monitored frequently by the supervisory authority. The central bank or the supervisory authority should also have the power to take remedial actions against the bank when the LOLR support loan is outstanding, such as changing the management or imposing a conservatorship, particularly when the loan has to be rolled over. The conditions attached should be more stringent if the underlying solvency of the borrowing bank is in serious doubt or if there is not sufficient collateral of acceptable 
quality. Such conditions may include restrictions on a bank's ability to take on new business and a moratorium on dividend payment.

In Israel, the Bank of Israel Law stipulates that "so long as the loan has not been repaid in full, the borrowing corporation shall not grant or extend any credit, or make any other investment without the prior approval of the Bank." The central bank laws in Korea and the Philippines have similar stipulations. In Kyrgyzstan, the law requires that "during the life of such a loan, the Bank of Kyrgyzstan shall establish a special regime provided for in the regulations of the Bank of Kyrgyzstan in respect of the borrower." In Hungary, the National Bank of Hungary can grant liquidity support "dependent on the emergency measure to be taken by the State Money and Capital Market Supervision, and on the compliance of the given credit institution with the measure initiated by the said authority." In the Philippines, if the amount of the first tranche of central bank support needs to exceed 25 percent of the bank's total deposit and deposit substitutes, "the principal stockholders of the borrowing institution must furnish an acceptable undertaking to indemnify and hold harmless from suit a conservator whose appointment the Monetary Board may find necessary at any time."

\section{The Size Limit of LOLR Support}

Central banks may also impose a size limit on any LOLR support they may provide to financial institutions in order to limit their own exposure to credit risks. In Argentina, the central bank law stipulates that liquidity support loans from the central bank should not exceed the net worth of the borrowing institution. In Hong Kong, the limit would normally be set between 100 percent to 200 percent of the capital base of the institution concerned depending on the margin of solvency the institution can maintain, subject to a cap of HK $\$ 10$ billion. It is emphasized that the HKMA retains the discretion to lend less than the maximum. In Turkey, the law requires that central bank emergency loans should not exceed twice the capital of the borrowing institution. In the Philippines, the amount of any emergency loan cannot exceed the sum of 50 percent of total deposits and deposit substitutes of the borrowing institution.

Whether it is necessary to impose a size limit to LOLR support is a controversial one. It can be argued that central bank lending limits make sense when such support is for monetary purposes, but not for emergency lending where one should follow Bagehot and be prepared to lend without limit (lend freely). If the limit on LOLR lending is too tight, it might encourage preventive runs on banks. On balance, the rationale for a size limit on emergency support facilities is not strong and, if it is introduced, the limit should not be too tight.

\section{E. The Terms of Repayment}

A key concept in LOLR support is that any emergency lending should be only temporary and for the short-term. Troubled banks seeking loans from the central bank may be likened to individuals seeking assistance from hospital emergency-room personnel. Providers of either form of assistance perform simultaneously a first-aid function and a triage function. Central bank liquidity assistance should seek only to keep the bank going until a 
more authoritative examination can determine the institution's long-term viability (Benston et al, 1986). Any institution which has to rely on central bank liquidity assistance for more than a few weeks is an indication that the institution is likely to be insolvent and the authorities should be ready to have it closed and resolved. Conversely, there should also be incentive for the central bank to lend only for the short term. For example, the Federal Reserve Act stipulates that the Federal Reserve should be penalized by making a payment to the FDIC if it makes emergency loans for an extended period of time, as discussed earlier.

Central bank laws or regulations typically stipulate explicitly that liquidity support from the central bank is only for the short term. In Argentina, the central bank law requires that central bank advances to banks to relieve temporary illiquidity should not exceed thirty days. The approval of an absolute majority of the board of directors of the central bank is required to extend the maturity of the loan. In Chile, the central bank law stipulates that liquidity support to banks cannot be outstanding for more than ninety days, and the approval of a majority of the Board is required to extend the maturity of the loan; the Superintendency of Banks and Financial Institutions should also be notified in advance before extending the maturity of the loan. In Hong Kong, the HKMA policy statement on LOLR states that liquidity support will be provided for an initial term not exceeding 30 days although there will be provisions for it to be rolled over for a further 30 days on maturity.

\section{F. Default Situations}

Where LOLR support is not repaid on maturity and the central bank is not prepared to rollover the funding, the central bank should take immediate actions, in cooperation with the supervisory authority, to have the borrowing bank resolved, including withdrawing its licenses, imposing receivership, and starting liquidation.

In practice, a particularly difficult situation is how to resolve the default situation of those institutions that are considered "too big to fail (TBTF)." As Garcia (2000) pointed out, as long as the owners and managers of a failed bank are not bailed out and there is an operational and financial restructuring to restore viability to the bank, a TBTF policy means that the government saves the economic infrastructure of the bank, absorbs the losses, and often assumes ownership temporarily until re-privatization. If the initial restructuring measures do not make the bank viable, drastic measures should be taken. These measures could involve splitting up the bank, partially liquidating it, or engineering a major shrinkage of its balance sheet through structural and/or operational downsizing.

\section{G. Confidentiality of LOLR Support}

Central banks tend to conduct LOLR operations in private and to try to keep the fact that they are providing emergency support secret at the time. Since the health of a banking system depends in part on the confidence that the public has in the system, and since confidence may decline if it is known that a rescue has been mounted, there is an argument 
that the most efficient provision of LOLR support is one that is not seen. ${ }^{20}$ In addition, if the fact that an otherwise sound bank is seeking liquidity support from the central bank becomes known to the market, the borrowing bank is likely to suffer a reputational cost and its borrowing cost would be driven up. This is undesirable for the restoration to health by the bank. On the other hand, as argued earlier, while immediate public disclosure may undermine efforts to support a particular institution or group of institutions, ex post disclosure with an appropriate delay is important to ensure the credibility and accountability of the central bank.

\section{Emergency Liquidity Support in Times of Systemic Crises}

In times of systemic crises, the central bank, as lender of last resort, attempts to assure the public that it will act firmly and limit the scope of any financial disturbance. It may be necessary to provide support to all banks short of liquidity in the initial stage. In a widespread crisis situation, the criteria to judge whether an institution is systemically important may have to be relaxed as compared to normal times. In addition, emergency liquidity support is usually needed when a full guarantee of deposits is offered by the government. Initially, the full guarantee may well not be credible and the runs could continue unless central bank liquidity support is provided in large amounts. In such a situation, the modalities of LOLR support may need to be adapted from those described in the preceding sections.

Firstly, in a general environment of panic and instability, the existence and presence of an emergency lender should not be doubted by the market participants. Therefore, public announcements by central banks of their willingness to lend whatever is necessary to calm the situation becomes an important tool of crisis management. ${ }^{21}$ Central bank support should be visible and should be provided speedily. Interest rates should be somewhat above the average market rates to encourage banks to seek alternative sources before approaching the central bank for support, but the penalty should not be excessively high. Importantly, the borrowing institution should be subject to restrictions on activities, and intensive supervisory monitoring, including inter alia, how the borrowed funds are being used.

\footnotetext{
${ }^{20}$ It is also possible to conceive circumstances where it might be useful for the central bank support to be known in the market (for example, when the bank faces run by retail depositors).

${ }^{21}$ Public pronouncements should be reassuring but minimal to avoid misinterpretation. The statement of the Federal Reserve Chairman, at 8:15 a.m., before the markets opened on Terrible Tuesday, in October 1987 during the stock market crash, met these specifications: "The Federal Reserve System, consistent with its responsibilities as the nation's central banker, affirmed today its readiness to serve as the source of liquidity to support the economic and financial system" (Garcia, 1989).
} 
Secondly, the usual preconditions of support such as solvency and collateral requirements may not be applied. This is because, in a systemic crisis, the solvency and soundness of collateral of financial institutions depend to a large extent on how the crisis is managed and whether the panic is stopped or not. In an environment of large volatility in asset prices such as interest rates and exchange rates, it can be very difficult to differentiate mere illiquidity from insolvency. In addition, limits on repayment terms may have to be relaxed to accommodate the implementation of a systemic bank restructuring plan.

In general, emergency liquidity support in times of systemic crisis should be an integral part of a comprehensive and well designed crisis management strategy. ${ }^{22}$ As such, decisions on whether to provide support and how much to lend should be made jointly by the relevant authorities, including the central bank, the supervisory agency, the deposit insurance fund, and the ministry of finance. There should be appropriate documentation of the decision process and ex post disclosure of the outcomes of major decisions, in order to ensure public accountability.

In Sweden, during the banking crisis in the early 1990 s, the banking system was free to obtain unlimited liquidity by drawing on its accounts with the central bank, and the Riksbank supplied liquidity on a relatively large scale at normal interest rates and repayment terms. Because the government issued a blanket guarantee, ${ }^{23}$ the Riksbank did not take on credit risks by making such loans. The details of the authorities' support measures, and their implications for depositors and investors, were extensively reported both domestically and abroad to financial market participants. ${ }^{24}$

When a major part of the banking system is insolvent, resources for solvency support should come from the government and private sector, not the central bank, and any public costs should be recognized explicitly. The government may decide that the central bank should provide support until a systemic restructuring strategy is in place, and perhaps thereafter; but such credit would normally be explicitly guaranteed by the government. Transparency would require that if such loans cannot be repaid by the institution (i.e., when it is necessary to call on the guarantee), the government should compensate the central bank for the losses.

${ }^{22}$ See Lindgren et al (1999), Garcia (2000), and Enoch (2000).

${ }^{23}$ In the face of a severe banking crisis, the Swedish parliament in 1992 passed a bill stating, inter alia, that "the state guarantees that banks and certain other credit institutions can meet their commitments in a timely basis," that "the support system is to remain available for as long as it is needed" (subject to another act of parliament), and that "the support is constructed so that all the commitments of an institution can be met."

${ }^{24}$ See internal MAE Office Memorandum dated July 2, 1999 by Charles Siegman, Matthew Jones, Dmitri Menchikov, and Akihiro Kanaya. 
One option is for the central bank not to transfer any profits to the government until all losses are covered. However, the central bank is not usually in a position to make any profits after making large nonperforming loans to insolvent banks. More typically, the claims by the central bank on the insolvent banks are converted into equity of the bank held by the government, and the government would, in exchange, issue securities to be held on the balance sheet of the central bank. It is very important that these securities be issued on market terms and be marketable for the central bank to be properly recapitalized. 


\section{Provisions on Emergency Liquidity Support in Selected Central Bank Legislation}

\begin{tabular}{|c|c|}
\hline ARGENTINA & $\begin{array}{l}\text { Article 17. The bank shall be authorized to carry out the following operations: (b) grant rediscounts to financial institutions for reasons of } \\
\text { temporary illiquidity, not to exceed thirty (30) consecutive days, up to a maximum per institution equivalent to its net worth; (c) grant } \\
\text { advances on account to financial institutions for reasons of temporary illiquidity, not to exceed thirty (30) consecutive days, that are } \\
\text { guaranteed by public securities or other securities, or covered by a guarantee or special or general appropriation of certain assets, provided } \\
\text { that the sum of the rediscounts or advances granted to one and the same institution does not exceed, under any circumstances, the limit } \\
\text { established in the foregoing section. } \\
\\
\text { When necessary to provide adequate liquidity to the financial system, or when general or extraordinary circumstances make it advisable in } \\
\text { the opinion of an absolute majority of the board of directors, the terms and ceilings per institution provided in (b) above and in the first } \\
\text { paragraph of (c) may be exceeded, as long as the free reserves supporting the monetary base are not to this end compromised under any } \\
\text { circumstances. When such extraordinary financing is granted, the shareholders shall, in addition to the guarantees constituted by the assets } \\
\text { of the institution, pledge, as a minimum, the control share capital of the institution and shall agree to the possible later application of the } \\
\text { procedure set out in Article } 35 \text { bis of the Law on Financial Institutions. Official banks may be exempted from this requirement. }\end{array}$ \\
\hline$\overline{\mathrm{BOT}}$ & $\begin{array}{l}\text { rticle } 37.3 \text { Operations with account holders. The central bank may, on such terms and conditions as the board may from time to time } \\
\text { termine, grant to account holders loans and advances for periods not exceeding } 92 \text { days-(b) unsecured or secured by such other assets, } \\
\text { such special terms and conditions as the board shall determine when, in its opinion, such a loan or advance is exceptionally necessary } \\
\text { meet the liquidity requirements of the borrower. }\end{array}$ \\
\hline$\overline{\text { BUL }}$ & $\begin{array}{l}\text { Article 33. (1) The Bulgarian National Bank may not extend credits to banks, except in the cases under para 2. (2) Upon emergence of a } \\
\text { liquidity risk that may affect the stability of the banking system, the Bulgarian National Bank may extend to a solvent bank } \\
\text { lev-denominated credits with maturity no longer than three months, provided they are fully collateralized by gold, foreign currency or } \\
\text { other such high-liquid assets. The terms and procedure for extension of such credits, as well as the criteria establishing the occurrence of a } \\
\text { liquidity risk, shall be determined by a regulation of the Bulgarian National Bank. (3) Credits under para. } 2 \text { may be extended solely up to } \\
\text { the amount of the excess of the lev equivalent of the gross international foreign exchange reserves over the total amount of monetary } \\
\text { liabilities of the Bulgarian National Bank. }\end{array}$ \\
\hline C & $\begin{array}{l}\text { ticle 36. The Authority to Safeguard the Stability of the Financial System. For the purpose of safeguarding the stability of the financial } \\
\text { tem, the bank shall be empowered to: grant banking and financial institutions loans in case of emergency for a period not to exceed } 90 \\
\text { ys, when the problems stem from a temporary shortage of liquidity. To renew these loans, a Board decision adopted by a majority of the } \\
\text { I membership, with a prior report to the Superintendency of Banks and Financial Institutions shall be required. The bank may make the } \\
\text { inting of loans contingent upon compliance by the borrower with particular rules of financial administration. In the situation foreseen in } \\
\text { s numeral, the bank may, accordingly, acquire instruments from the placement or investment portfolios of the above-mentioned } \\
\text { titutions. }\end{array}$ \\
\hline
\end{tabular}




\begin{tabular}{|c|c|}
\hline HUNGARY & $\begin{array}{l}\text { Article 17. Extraordinary Credit for Credit Institutions in Emergency Situations. The National Bank of Hungary may grant an } \\
\text { extraordinary credit to a credit institution in case of emergency of the credit institution. The NBH may make the granting of such a loan } \\
\text { dependent on the emergency measure to be taken by the state money and capital market supervision, and on the compliance of the given } \\
\text { credit institution with the measure initiated by the said authority. }\end{array}$ \\
\hline ISRAEL & $\begin{array}{l}\text { Part Eight: Credit Operations of the Bank } 44 \text {. Emergency loans and advances. The governor, in circumstances which, in his opinion, are } \\
\text { emergency circumstances, may direct that loans are granted even to a banking corporation unable to fulfill the conditions prescribed under } \\
\text { section } 43 \text { if such corporation has given security to his satisfaction, and may further direct that so long as the loan has not been repaid in } \\
\text { full the borrowing corporation shall not grant or extend any credit, or make any other investment, without the prior approval of the bank. }\end{array}$ \\
\hline JAPAN & $\begin{array}{l}\text { Article 37.1. The Bank of Japan (BOJ), irrespective of the provisions of Article 33, Paragraph 1, may provide uncollateralized loans to } \\
\text { financial institutions (defined as those engaged in the business of taking bank deposits (deposits prescribed by Article } 2 \text {, Paragraph } 2 \text { of } \\
\text { the Deposit Insurance Law, Law No. } 34 \text { of 1971) as well as engaging in exchange transactions, the same definition shall apply hereinafter) } \\
\text { and other financial business entities prescribed by a Cabinet Order (hereinafter referred to as "financial institutions" together) for a period } \\
\text { within that prescribed by a Cabinet Order when they unexpectedly experience a temporary shortage of funds for payment due to } \\
\text { accidental causes, including computer system problems, whereby the business operations of the financial institutions may be seriousiy } \\
\text { hampered if the shortage is not recovered swiftly, provided that the advance is necessary to secure the smooth settlement of funds among } \\
\text { financial institutions. } \\
\text { Article 37.2. The BOJ shall, when providing loans as prescribed by the preceding paragraph, report the fact to the minister of finance as } \\
\text { well as inform the commissioner of the financial supervision agency of the fact without delay. } \\
\text { Article } 38.1 \text {. The minister of finance may request that the Bank of Japan conduct the business necessary to maintain an orderly financial } \\
\text { system, including provision of loans, when it is believed to be especially necessary for the maintenance of an orderly financial system } \\
\text { including the case where it is judged, after consultation with the prime minister pursuant to the provisions of Article } 57-2 \text { of the Banking } \\
\text { Act (Law No. } 59 \text { of } 1981 \text { ) and other relevant laws and regulations that a serious problem in an orderly financial system may arise. } \\
\text { Article 38.2 At the request of the minister of finance as prescribed by the preceding paragraph, the bank may conduct business necessary } \\
\text { to maintain an orderly financial system, including provision of loans under special conditions, in addition to the business prescribed by } \\
\text { Article 33, Paragraph } 1 \text {. }\end{array}$ \\
\hline JORDAN & $\begin{array}{l}\text { Article } 41 \text { (C). The central bank may, in cases of emergency, or under extraordinary circumstances which, in the opinion of the central } \\
\text { bank, constitute a threat to monetary or banking stability in the kingdom, extend special credit facilities to any licensed bank under such } \\
\text { terms and conditions established by the board and approved by the council of ministers. }\end{array}$ \\
\hline KOREA & $\begin{array}{l}\text { Article } 65 \text { (Emergency Credit to Banking Institutions) } \\
\text { (1) The Bank of Korea (BOK) may conduct credit operations against the collateral of any assets which are defined temporarily as } \\
\text { acceptable security with at least four members concurring in any of following cases: } \\
\text { 1. Conducting credit operations temporarily with banking institutions during a grave emergency that directly threatens monetary and } \\
\text { banking stability; or } \\
\text { 2. Conducting credit operations temporarily with banking institutions that are expected to experience pronounced difficulty in carrying out } \\
\text { their operations due to temporary shortages of funds for payment caused by a breakdown of an electronic information processing system }\end{array}$ \\
\hline
\end{tabular}




\begin{tabular}{|c|c|}
\hline & $\begin{array}{l}\text { or other accidental mishap. } \\
\text { (2) A banking institution in receipt of credit specified in the provisions of Clause } 1 \text { of paragraph (1) may not, while such debt is } \\
\text { outstanding, increase the total volume of its loans and investments without prior authorization by the Monetary Policy Committee. } \\
\text { (3) The BOK may, when it deems necessary, check and confirm the operations and status of the assets of a banking institution in } \\
\text { connection with extension of credit as provided for in Paragraph (1). }\end{array}$ \\
\hline KYRGYZSTAN & $\begin{array}{l}\text { Article 4. Functions of the Bank of Kyrgyzstan. The bank shall have the following functions: } \\
\text { (4) acting as the lender of last resort to banks in accordance with the present Law; } \\
\text { Article } 28 \text {. Loans Granted to Other Banks. In emergency situations, in order to protect the integrity of the banking system, the Bank of } \\
\text { Kyrgyzstan may make unsecured loans or loans secured by other types of assets, on terms established by the board of directors of the } \\
\text { bank. An emergency loan may be granted for a term of not more than six months. This term may be extended by a decision of the board of } \\
\text { directors of the bank. During the life of such a loan, the bank shall establish a special regime provided for in the regulations of the bank in } \\
\text { respect of the borrower. }\end{array}$ \\
\hline MADAGASCAR & $\begin{array}{l}\text { Article 34. Central Bank Assistance to Banks and Financial Institutions. In the event of temporary liquidity problems experienced by a } \\
\text { bank or financial institution in connection with the implementation of a recovery plan acceptable to the Bank and Financial Institutions } \\
\text { Control Commission and the central bank, the latter may grant such institutions a special advance on the conditions adopted by the board. } \\
\text { Article 38. The central bank may make its assistance contingent on the submission of any documentation it deems necessary. It may, as } \\
\text { appropriate, require that any real or personal guarantees be provided. }\end{array}$ \\
\hline MEXICO & $\begin{array}{l}\text { Article 3.- The bank shall perform the following functions: II. Operate as reserve bank and lender of last resort for credit institutions; } \\
\text { Article 15.- Provisions in Article } 8 \text { paragraph two and Article 14, will not apply to financing that the central bank may grant credit } \\
\text { institutions in order to prevent disruptions in the payment systems, nor to operations effected by the bank as lender of last resort. }\end{array}$ \\
\hline NEW ZEALAND & $\begin{array}{l}\text { Article 31. Bank to Act as Lender of Last Resort-The bank shall, if the bank considers it necessary for the purpose of maintaining the } \\
\text { soundness of the financial system, act as lender of last resort for the financial system. }\end{array}$ \\
\hline NORWAY & Section 19 . When warranted by special circumstances, the bank may grant credit on special terms. \\
\hline PHLLPPINES & $\begin{array}{l}\text { SECTION 83. Loans for Liquidity Purposes.- The Bangko Sentral may extend loans and advances to banking institutions for a period } \\
\text { of not more than seven (7) days without any collateral for the purpose of providing liquidity to the banking system in times of need. } \\
\text { SECTION 84. Emergency Loans and Advances. - In periods of national and/or local emergency or of imminent financial panic, which } \\
\text { directly threaten monetary and banking stability. The Monetary Board may, by a vote of at least five (5) of its members, authorize the } \\
\text { Bangko Sentral to grant extraordinary loans or advances to banking institutions secured by assets as defined hereunder: Provided that } \\
\text { while such loans or advances are outstanding, the debtor institution shall not, except upon prior authorization by the Monetary Board, } \\
\text { expand the total volume of its loans or investments. } \\
\text { The Monetary Board may, at its discretion, likewise authorize the Bangko Sentral to grant emergency loans or advances to banking } \\
\text { institutions, even during normal periods, for the purpose of assisting a bank in a precarious financial condition or under serious financial } \\
\text { pressures brought by unforeseen events, or events which, though foreseeable, could not be prevented by the bank concerned: Provided, } \\
\text { however, that the Monetary Board has ascertained that the bank is not insolvent and has the assets defined hereunder to secure the } \\
\text { advances: Provided, further, that a concurrent vote of at least five (5) members of the Monetary Board is obtained. }\end{array}$ \\
\hline
\end{tabular}




\begin{tabular}{|c|c|}
\hline & 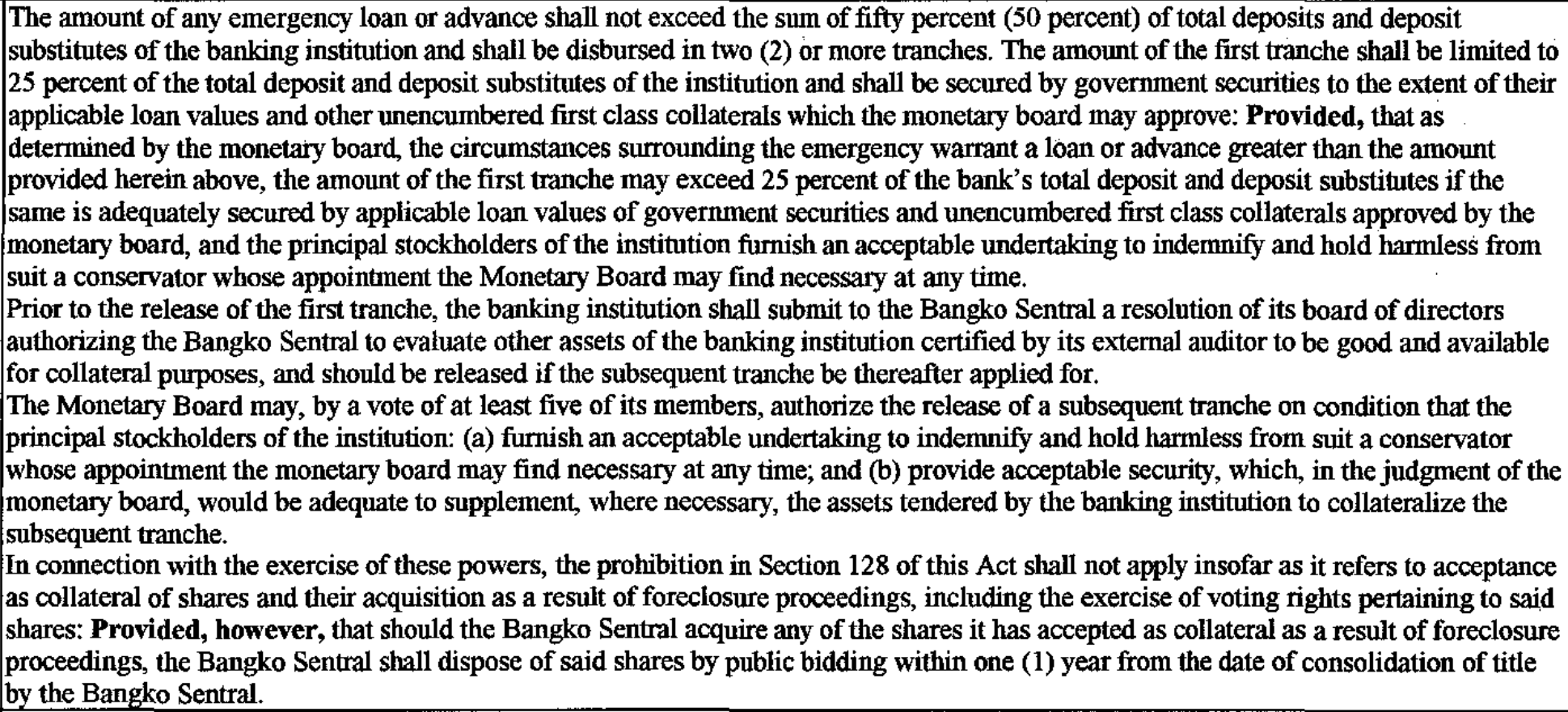 \\
\hline POLAND & $\begin{array}{l}\text { Article } 42.3 \text { The National Bank of Poland (NBP) may also extend refinancing to banks for the implementation of a bank rehabilitation } \\
\text { program. } 4 \text {. Refinancing facilities may be granted: (1) up to a specified amount, as a line of credit; (2) against pledges of securities, up to } \\
\text { an amount corresponding to a specified proportion of the face value of such securities (Lombard facilities), (3) in other forms, as specified } \\
\text { by the NBP Management Board. }\end{array}$ \\
\hline ROMANIA & $\begin{array}{l}\text { Article 27. Protection against systemic risk. In order to mitigate systemic and payment risks, in exceptional circumstances and on a case- } \\
\text { to-case basis, the National Bank of Romania may grant to banks loans that are either unsecured or secured with assets other than those } \\
\text { provided for in Art. } 20 \text { hereof. }\end{array}$ \\
\hline
\end{tabular}




\begin{tabular}{|c|c|}
\hline SWEDEN & $\begin{array}{l}\text { Art. 8. In exceptional circumstances, the Riksbank may, with the end of supporting liquidity, grant credits or provide guarantees on } \\
\text { special terms to banking institutions and Swedish companies that are under the supervision of the Financial Supervisory Authority. }\end{array}$ \\
\hline TURKEY & $\begin{array}{l}\text { Art. 40, II. (d) The Bank may, within the framework of sub-paragraph (b) of Article } 36 \text { of this Law, extend credits directly to banks within } \\
\text { the scope of Article } 64 \text { of the Banking Law and to those that are the subject of uncertainty and lack of confidence due to the acceleration } \\
\text { of the fund withdrawals or because of uncertainty and lack of confidence in the banking system, provided that the credits are extended } \\
\text { against appropriate collateral and be limited to a maximum of one year maturity and twice the amount of the equity-capital. }\end{array}$ \\
\hline $\begin{array}{l}\text { UNITED } \\
\text { STATES }\end{array}$ & 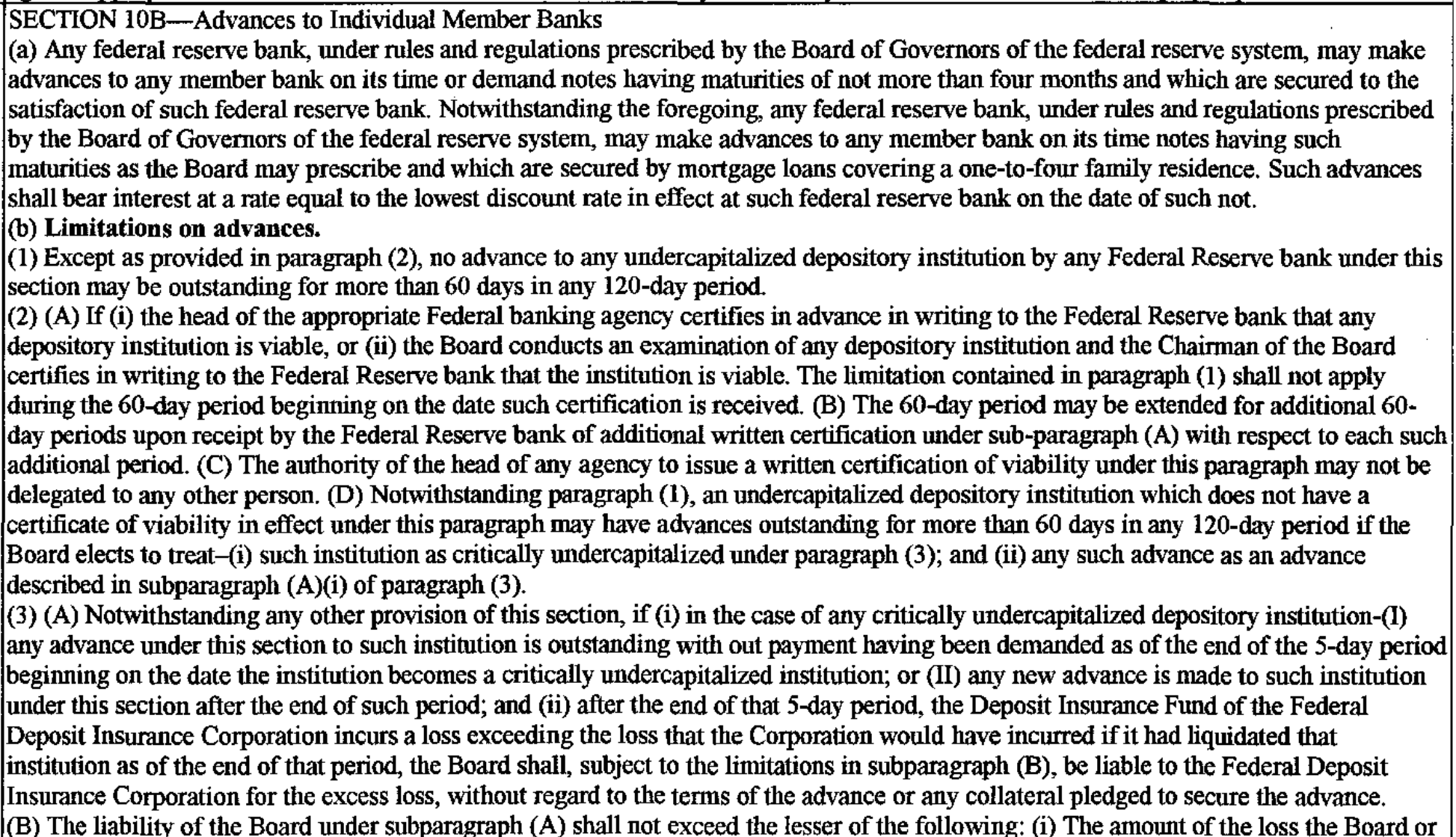 \\
\hline
\end{tabular}




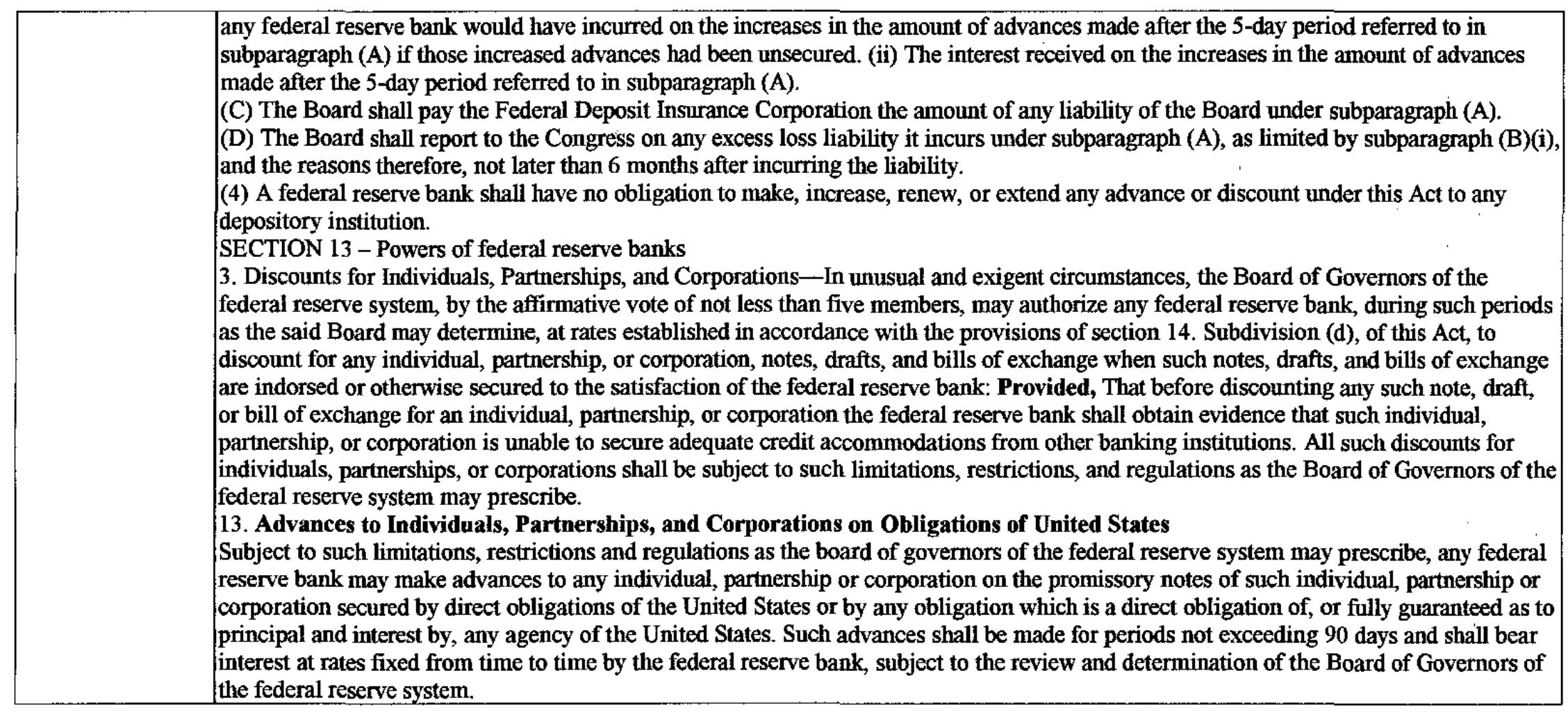




\section{Bibliography}

Bagehot, Walter, 1873, Lombard Street: A Description of the Money Market (London: William Clowes and Sons).

Baxter, Thomas C., Jr. and Joseph H. Sommer, 1999, "Lender-of-Last-Resort Issues-Past, Present, and Future," in Current Developments in Monetary and Financial Law (Washington: International Monetary Fund).

Benston, George, Robert Eisenbeis, Paul Horvitz, Edward Kane, and George Kaufman, 1986, Perspectives on Safe and Sound Banking: Past, Present, and Future (Cambridge, Massachusetts: MIT Press).

Bordo, Michael, 1990, "The Lender of Last Resort: Alternative Views and Historical Experience," Economic Review, Federal Reserve Bank of Richmond (January/February), pp. 18-29.

Brimmer, Andrew F., 1989, "Distinguished Lecture on Economics in Government: Central Banking and Systemic Risks in Capital Markets," Journal of Economic Perspectives, Vol. 3, Number 2, pp. 3-16.

Brock, Philip L, 1998, "Financial Safety Nets and Incentive Structures in Latin America," Policy Research Working Paper (Washington: The World Bank).

Calomiris, Charles W., 1994, "Is the Discount Window Necessary? A Penn Central Perspective," Review, Federal Reserve Bank of St. Louis (May/June).

Caprio, Gerard, Jr., Michael Dooley, Danny Leipziger, and Carl Walsh, 1996, “The Lender of Last Resort Under a Currency Board: The Case of Argentina," Policy Research Working Paper 1648 (Washington: The World Bank).

Claassen, Emil-Maria, 1985, "The Lender-of-Last-Resort Function in the Context of National and International Financial Crises," Weltwirtschaftliches Archiv, Vol. 121, No. 2, pp. 217-237.

Clouse, James A., 1994, “Recent Developments in Discount Window Policy," Federal Reserve Bulletin (November), pp. 965-977.

Corrigan, Gerald, 1990, "Reforming the U.S. Financial System: An International Perspective," Federal Reserve Bank of New York Quarterly Review (Spring).

Dziobek, Claudia, J. Kim Hobbs, and David Marston, "Toward a Framework for Systemic Liquidity Policy," Working Paper WP/00/34 (Washington: International Monetary Fund). 
Enoch, Charles, 2000, "Bank Interventions in Banking Crises: The Experience of Indonesia," Policy Discussion Paper PDP/00/ (Washington: International Monetary Fund).

_ Peter Stella, and May Khamis, 1997, "Transparency and Ambiguity in Central Bank Safety Net Operations," Working Paper WP/97/138 (Washington: International Monetary Fund).

Fischer, Stanley, 1999, "On the Need for an International Lender of Last Resort," Journal of Economic Perspectives, Vol. 13, No. 4, pp. 85-104.

Flannery, Mark J., 1996, "Financial Crises, Payment System Problems, and Discount Window Lending," Journal of Money, Credit, and Banking, Vol. 28, No. 4, pp. 804-831.

Freixas, Xavier, Curzio Giannini. Glenn Hoggarth, Farouk Soussa, 1999, "Lender of Last Resort: A Review of the Literature," Financial Stability Review, Vol. 7, pp. 151-167, (London: Bank of England).

Garcia, Gillian, 1989, "The Lender of Last Resort in the Wake of the Crash," American Economic Review (May), Vol. 79, No. 2, pp. 151-155.

_____. 2000, "Deposit Insurance and Crisis Management," Working Paper WP/00/57 (Washington: International Monetary Fund).

(Cambridge, Massachusetts: Ballinger).

George, Eddie, 1993, "The Pursuit of Financial Stability," Central Banking, Vol. 4, No. 3, pp. 22-35.

Giannini, Curzio, 1998, "Enemy of None But a Common Friend to All? An International Perspective on the Lender-of-Last-Resort Function," IMF Working Paper WP/99/10 (Washington: International Monetary Fund).

Goodfriend, Marvin and Robert King, 1988, "Financial Deregulation, Monetary Policy, and Central Banking," in W. S. Haraf and R. M. Kushmeider (eds), Restructuring Banking and Financial Services in America (Washington: American Enterprise Institute for Public Policy Research).

Goodhart, Charles A. E., 1995, The Central Bank and the Financial System (Cambridge, Massachusetts: MIT Press).

Goodhart, Charles A.E., 1999, "Myths About the Lender of Last Resort," International Finance, Vol. 2, No. 3. 
— , and Haizhou Huang, 1998, "A Model of the Lender of Last Resort," IMF Working Paper WP/99/39 (Washington: International Monetary Fund).

—, and Dirk Schoenmaker, 1993, "Institutional Separation Between Supervisory and Monetary Agencies," in Goodhart (1995).

Guttentag, Jack and Richard Herring, 1983, "The Lender-of-Last-Resort Function in an International Context," Princeton University Essay in International Finance No. 151 (May).

Hirsch, Fred, 1977, “The Bagehot Problem," The Manchester School, Vol. 45, No. 3 (September), pp. 241-257.

Humphrey, Thomas, 1975, “The Classical Concept of the Lender of Last Resort," Federal Reserve Bank of Richmond Economic Review, Vol. 61 (February), pp. 2-9.

— Journal, Vol. 4, No. 1, pp. 275-321.

Folkerts-Landau, David and Carl-Johan Lindgren, 1998, Toward a Framework for Financial Stability, World Economic and Financial Surveys (Washington: International Monetary Fund).

Carl-Johan Lindgren and others, 1999, Financial Sector Crisis and Restructuring-Lessons from Asia, IMF Occasional Paper No. 188 Washington: International Monetary Fund).

Kaufman, George, 1991, "Lender of Last Resort: A Contemporary Perspective," Journal of Financial Services Research, Vol. 5, pp. 95-110.

Kindleberger, Charles, 1978, Manias, Panics, and Crashes: A History of Financial Crisis New York: Basic Books).

Meltzer, Allan, 1986, "Financial Failures and Financial Policies" in G. G. Kaufman and R. C. Kormendi (eds), Deregulating Financial Services: Public Policy in Flux (Cambridge, Massachusetts: Ballinger).

Mishkin, Frederic S., 1991, "Anatomy of a Financial Crisis," NBER Working Paper \#3934.

Padoa-Schioppa, Tommaso, 1999, "EMU and Banking Supervision," available via internet: http://www.ecb.int/key/sp990224.htm.

Prati, Alessandro and Garry Schinasi, 1998, "Financial Stability in EMU," (Washington: International Monetary Fund). 
Quinn, Brian, 1996, "Rules v. Discretion: The Case of Banking Supervision in the Light of the Debate on Monetary Policy," LSE Financial Markets Group, Special Paper No. 85.

Rockoff, Hugh, 1986, "Walter Bagehot and the Theory of Central Banking" in F. Capie and G. E. Wood (eds), Financial Crises and the World Banking System (New York: St. Martin's Press).

Schwartz, Anna, 1988, "Financial Stability and the Federal Safety Net" in W. S. Haraf and G. E. Kushmeider (eds), Restructuring Banking and Financial Services in America (Washington: American Enterprise Institute for Public Policy Research).

Solow, Robert, 1982, "On the Lender of Last Resort" in C. P. Kindleberger and J. P. Laffargue (eds), Financial Crisis: Theory, History, and Policy (Cambridge: Cambridge University Press).

Thornton, Henry, 1802, An Enquiry into the Nature and Effects of the Paper Credit of Great Britain. Edited by F. A. Hayek (Fairfield: Augustus M. Kelley Publishers) (Reprint, 1978).

Yam, Joseph, 1999, "The Lender of Last Resort," speech at Hong Kong Association of Banks, available via internet:

http://www.info.gov.hk/hkma/eng/speeches/speechs/joseph/speech_290699b.htm 